\author{
Antoni Remesar \\ (iD) https://orcid.org/0000-0002-1145-6279 \\ Scopus Author ID: 55323348400 \\ Researcher ID: J-9745-2016 \\ Polis Research Centre, CRIT Research Group \\ Universitat de Barcelona \\ aremesar@ub.edu
}

\title{
TWENTY YEARS WORKING WITH NEIGHBOURS CITIZEN PARTICIPATION, IS IT POSSIBLE? WHAT WE HAVE LEARNED IN 20 YEARS
}

\begin{abstract}
In 1999, the Governing Council of the Universitat de Barcelona approved the creation of the POLIS Research Center. Later, in 2016, the Center was ratified after passing an assessment of the Catalan Accreditation Agency (AGAUR). The Centre has an interdisciplinary vocation and brings together researchers from different research groups at the University of Barcelona and cooperates with nine European and Ibero-American universities in the fields of Arts, Architecture and Human and Social Sciences. Academically, the Centre has promoted the doctoral program Public Space and Urban Regeneration (1998-2017) and the Master's Degree in Urban Design: Art, City, Society (since 2007) and the publication of the journal On thew@terfront. The research object of the Centre is the city and its public space and, more specifically, the role of citizens in the production of Public Art and Urban Design. For this reason, the work of the Centre covers the topics related to Urban Regeneration, Sustainability, Urban Governance, Civic Remembrance, Heritage. Throughout its twenty-year history, the Centre has developed a series of projects for citizen participation in various areas of the periphery of Barcelona: River Besòs (municipality of Sant Adria de Besos) La Mina neighbourhood (municipality of Sant Adrià de Besòs) and the Barcelona's neighbourhoods of Baró de Viver and Bon Pastor. A characteristic of the work of the centre has been, and is, the endorsement of citizen participation, through an innovative approach based on enabling the creative empowerment of the neighbours within the framework of Participatory Action Research. This approach is based on a project methodology, as it is understood in various project disciplines from Art to Architecture, from Design to Engineering. This article, associated with the itinerant exhibition "20 years working with neighbours," reviews the founding project carried out by the Centre, "Social Uses of the River Besòs" (1997-1999), analysing the lessons learned, with the aim of clarifying the research criteria that the Centre follows for the development of citizen participation projects.
\end{abstract}

\section{Keywords:}

citizen participation; urban governance; public space; urban design; public art; urban regeneration; bottom-up processes. 


\section{INTRODUCTION}

For one and a half year we developed the project "Re-thinking the river: Social Uses of the Besòs River," a Citizen Participation Project in the framework of a collaboration agreement between the City Council of Sant Adrià de Besòs and the Centre as developer of the Research Project PB95-0897 was funded by the Spanish Ministry of Research.

Sant Adrià of Besòs ${ }^{1}$ gets its name from the river Besòs, a strange and dangerous river like most of the Mediterranean rivers. The river divides the city in two big areas, thus marking a territorial and social division of the city. Some of the degraded neighbourhoods in the Metropolitan Region of Barcelona are concentrated on the right riverbank. It is this territory that, nowadays, is being planned as the territory in which the great Barcelona can close the urban development of its waterfront.

In 1998, the urban agency Barcelona Regional ${ }^{2}$ commissioned by the Consorci Besòs, ${ }^{3}$ proposed a plan for development of the area that, among other things, contemplates the environmental recovery of the whole Besòs river with the intention of transforming it into a great metropolitan river park. This plan included overlooking the Forum of Cultures in 2004, involving the creation of a multipurpose space of 14 ha, the construction of the marina of Sant Adrià, the creation of a coastal park and the channelling of the Besòs river for sports uses.

At first sight it seems a good idea, but is this project good for Sant Adrià's development? Is the proposed project the best one possible? Are the social needs of the population properly addressed?

\section{THE PARTICIPATORY PROJECT}

Trying to answer these questions, and in order to study the possibility of the river becoming the centre of town, as the linchpin of the city, we implemented this participatory workshop under the request of the Sant Adri's City Council, starting in late 1997 and finishing just before the local elections in 1999.

\footnotetext{
${ }^{1}$ Sant Adrià of Besòs is a small town (35.000 inhabitants) bordering with Barcelona. Historically it has been a territory without municipal entity, until, with the Regional Plan of 1953, the territorial planning of Franco conferred municipal statute to the territory. In the years of industrial development, Sant Adrià of Besòs became a kind of a metropolitan dump through the establishment along the river of polluting industry, as well as metropolitan facilities (power plants, water treatment plants, etc.).

${ }^{2}$ See Barcelona Nous Projectes/Barcelona New Projects (Barcelona: Ajuntament de Barcelona, Barcelona Regional, 1999).

${ }^{3}$ The Consoci Besòs is an administrative unit in charge of the project. It is formed by the Municipalities of Barcelona and Sant Adrià.
} 
Usually, civic participation processes are outlined from the social sciences and from the political praxis domain In general, these processes become a strategy of problem detection and consultation activities trying to find possible solutions, so the citizens participation is limited to the consultation pole of the of decision-making political processes. ${ }^{4}$

This was the objective of the town hall of Sant Adrià when it proposed the development of this process: to know the opinion of the citizens regarding the urban role of the Besòs River, at a time when the situation of the river exceeded the local limits, to become a regional problem (fig. 1). In the end, the implicit demand was to investigate the real possibilities of turning the Besòs into an articulating axis when the recovery process of the Besòs began. ${ }^{5}$

The City Council brought together the associations of the city (more than 70 were present), in an assembly in which the initial objectives of the process were stated. At the same time, representatives of 10 associations from both banks of the river were elected. These representatives formed the working group.

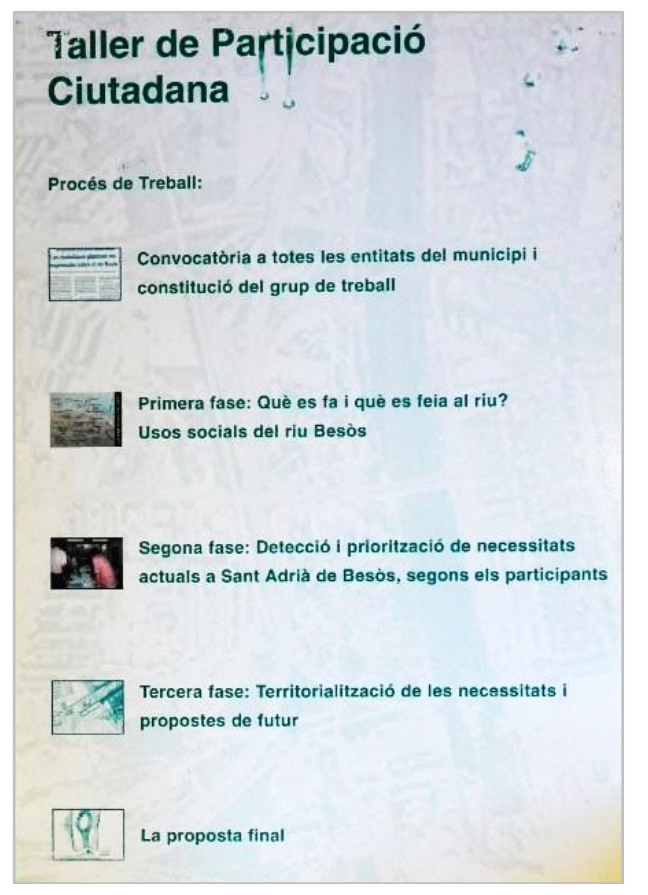

Fig. 1. Process development scheme.

[1] Call to all Associations and constitution of the working group.

[2] First step: What is done and what was done in the river? Social uses of the Besòs river.

[3] Second step: Detection and prioritization of the current needs in Sant Adrià, according to the participants.

[4] Third step: Territorialisation of needs and proposals for the future.

[5] Final proposal.

Source: Riu Besòs. Propostes de futur. Repensar el riu, panel of the exhibition, 1999

(Universitat de Barcelona, Besòs Viu, APRODISA, les associacions de veïns de La Mina i Sant Joan Baptista, Barnabitas, Centre Cultural Districte IV i Creu Roja).

\footnotetext{
${ }^{4}$ Sherry R. Arnstein, “A Ladder Of Citizen Participation," Journal of the American Institute of Planners 35, no. 4 (July 1969): 216-224, http://dx.doi.org/10.1080/01944366908977225; Cliff Moughtin, Urban Design: Street And Square, 3rd ed. (Oxford: Architectural Press, 2003).

${ }^{5}$ Lluís Cantallops et al., "El pla del marge dret del Besòs a Sant Adrià," Papers. Regió Metropolitana de Barcelona: Territori, estratègies, planejament, no. 13 (1993): 49-64.
} 


\subsection{Objectives and methodology of the process}

We can isolate diverse implicit objectives in the formulation of workshop in our participatory process.

Objective participation. ${ }^{6}$ The process had, as their first objective to develop the participation of the citizens with regard to thinking, planning and conforming public use proposals for the river, approaching, from a local perspective, the possible developments and action plans on this territory of the city.

Objective information. Through the development of the workshop and given the characteristics of the work, to seek a way of civic information based on the representability of the participants and to disseminate the information in their origin groups (neighbourhood groups, cultural associations, etc.).

Objective education. Through the development of the activity, we seek to educate the participants in technical subjects and to make them capable of territorial and urban analysis. Usually, this kind of training doesn't take place in the participative processes since the mediation of the technicians prevents citizens to develop their discursive and project capabilities. ${ }^{7}$ Participation in the workshop also proposes a way of learning how to consider the real distance between the desire or the expectations and the viability of the conclusions (fig. 2). ${ }^{8}$

Objective: extension to the community. The process and the results of the workshop enables, in a direct way, a good part of the population to "participate" in the discussion and critique of the results, while the workshop becomes an open process, open to new incorporations and to the opinions of the population as a whole.

\footnotetext{
${ }^{6}$ Our participatory process ran parallel to the study leading to implement the Regulation of citizen participation in Sant Adrià; Marco Marchioni, La utopía possible: la intervención comunitaria en las nuevas condiciones sociales (Tenerife: Editorial Benchomo, 1994); Marco Marchioni, Comunidad, participación y Desarrollo: Teoría y metodología de la intervención comunitaria (Madrid: Editorial Popular, 2001).

${ }^{7}$ Tom Angotty, "Advocacy and Community Planning: Past, Present and Future," Planners Network, April 22, 2007, https://www.plannersnetwork.org/2007/04/advocacy-and-communityplanning-past-present-and-future/; Henry Sanoff, Community Participation Methods in Design and Planning (New York: John Wiley and Sons, 2000); Jeremy Till, "The Negotiation of Hope," in Architecture and Participation, ed. Peter Blundell Jones, Doina Petrescu and Jeremy Till (London: Spon Press, 2005), 23-42.

${ }^{8}$ Matthew Carmona et al., Public Places - Urban Spaces. The Dimensions of Urban Design (Oxford: Architectural Press, 2003).
} 


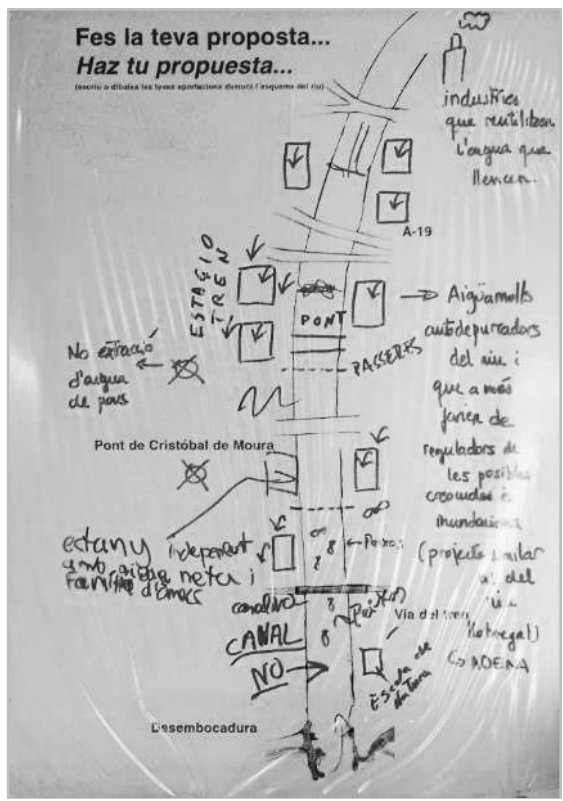

Fig. 2. Neighbours' writings (ideas and desires) on the specific participatory panel. Source: Riu Besòs. Propostes de futur. Repensar el riu, panel of the exhibition, 1999 (Universitat de Barcelona, Besòs Viu, APRODISA, les associacions de veïns de La Mina i Sant Joan Baptista, Barnabitas, Centre Cultural Districte IV i Creu Roja).

\subsection{Methodology}

Table 1. Phases of the process and its methodological deployment.

\begin{tabular}{|c|c|}
\hline \multicolumn{2}{|c|}{ Summary of the phases of the process and its methodological deployment } \\
\hline What to do (stages) & How to do it? (methods and techniques) \\
\hline $\begin{array}{l}\text { Demarcation of the topic to develop. } \\
\text { Yesterday - Today - Tomorrow. } \\
\text { Narrating the History }\end{array}$ & $\begin{array}{l}\text { - } \text { Walking } \\
\text { - Mapping } \\
\text { - Registering (pictures, video...) } \\
\text { - } \text { Registering memories }\end{array}$ \\
\hline $\begin{array}{l}\text { What the territory needs from the } \\
\text { social point of view. } \\
\text { Hierarchization / territorialisation of } \\
\text { the possible needs }\end{array}$ & $\begin{array}{ll}\text { - } & \text { Analysing } \\
\text { - } & \text { Comparing } \\
\text { - } & \text { Developing cognitive maps } \\
\text { - } & \text { "Zoning” on the map } \\
\text { - } & \text { Using swot techniques }\end{array}$ \\
\hline $\begin{array}{l}\text { Jumping to a Conceptualisation } \\
\text { or scenario design }\end{array}$ & $\begin{array}{l}\text { - Studying other projects about } \\
\text { the recovery of the Besòs River } \\
\text { - Documenting }\end{array}$ \\
\hline Shaping the form & $\begin{array}{ll}\text { - } & \text { Drawing } \\
\text { - } & \text { Modelling } \\
\text { - } & \text { Colouring } \\
\text { - } & \text { Documenting possible solutions } \\
\text { - } & \text { Designing } \\
\text { - } & \text { Producing a project draft } \\
\end{array}$ \\
\hline
\end{tabular}

Source: own study. 
From the initial meetings, the process articulates on the basis of an unusual method in participatory processes. The workshop introduces, as the nucleus of its activity, the project methodology. This methodology has characterised, up to now, the practice of such disciplines as Visual Arts, Architecture, Design or Engineering. It is a method in which the paper, the models, the pencil, the colour, the image, the analysis of the scales and proportions are placed in parallel or before the verbal discourse with the objective of shaping conclusions as graphic and operational forms for subsequent developments. Our methodology was sustained in five important pillars (cf. Table 1):

Demarcation of the topic to develop. Yesterday - Today - Tomorrow. Narrating the History. After the first meeting, we proceed to define and to delimit the topic on which the workshop will turn. In this phase it is very important to rescue the memory, to dive in the historical, anthropologic and cultural past. In parallel, an analysis of the present and current situation should be developed. The process runs in a dialectical way, detecting the problems and needs of the present and contrasting them with the data arising from memories. It is fundamental to discover that the data of the present are conditioned by the past, but, at the same time, that certain problems of the present can have the same solutions that existed in the past. This procedure provides signals and signs of identity which will define the development of the project.

What the territory needs from the social point of view. Hierarchization and territorialisation of the possible social needs. The in-depth exploration of the data of the present, making them visible and the development of imaginative proposals, will allow to overcome the weaknesses of the situation. The creative process begins. Once this work concludes, we begin the exercise of hierarchising the results in relation to their social importance for the population. This hierarchization should be accompanied by mapping the terrain activity when the issue requires "a location" in the territory of the city. Once defined, the issue should be developed so that we obtain a very clear map of what can be in favour of and against it.

Jumping to a Conceptualisation or scenario design. It is not possible to develop a project if it doesn't fit in a frame that warrants its meaning. This frame can be considered as a scenario ${ }^{9}$ that will guide the entirety of the project. The study and identification of this scenario that facilitates the creation of projects that are autonomous, of quality and, mainly, do not mimic the images that can be got from other possible solutions through the media or of other informative systems. This scenario design supposes, at the same time, to approach the local project from a wider perspective (locality-globality dialectics).

\footnotetext{
9 Jan Verwijnen, "Here and Nowhere. The Making of Urban Space," On the w@terfront, no. 2 (2000): 7-12, http://revistes.ub.edu/index.php/waterfront/article/view/18724
} 
Shaping the form. In a normal participation process, the workshop would have concluded its activity. In the previous phase it is possible to present a report that picks up the feasibility of the proposals. Later on, these proposals will be re-read and re-interpreted by the technical and political apparatus of the town and translated into a formal project. Our question was and still is are the neighbours able to develop "the forms" the contributed data would take?

Our methodology allows us to affirmatively answer this question. If the "technicians opinion" is our resource, a barrier will be lifted; a barrier that systematically operates between the citizens and the public administration. Obviously, the mediation of this barrier responds to a structure and operating system that has derived from a kind of "Enlightened despotism" the final solutions to the proposals or projects in such a way they cannot be contributed to by common humans since they require an interface of technical character. If we analyse our project methodology, we can find this argument lacks of foundation. The definition of the proposal's "form" implies two different stages. In the first phase, these proposals, shaped in sentences like "green areas," "recreational areas," etc., must be re-conceptualized in relation to the content parameter and to some general formal parameters. A green area can be a green area of grass or a Mediterranean green area of vegetation. Formally, these green areas can take diverse forms - those that the territory allows, those that we design (round, square, etc.). We outline that, in this first project phase, there are not technical impediments, only the possibility to formalise proposals endowing them with specific content and approaching certain formal solutions. This process can be carried out by common people. In essence this first phase allows us to establish those "managing directives" that are radically different from the materialisation of the project.

In the second phase the intervention of certain technicians is crucial, in order to evaluate the viability of the project proposal and to outline definitive solutions to the proposals contained in the projects. This is an important moment

\footnotetext{
10 "Enlightened Despotism? POLITICIANS. They think that basically people have no interest in public affairs. That is why politicians are elected democratically, no need to share power with anyone. If someone wants to participate, they should stand for election. From this perspective, no means are sought to incorporate ideas, initiatives or citizen proposals. TECHNICAL STAFF. The municipal technical staff already knows how to do everything without anyone saying anything. They are the connoisseurs of science and technology. They render accounts only to politicians. Citizens must submit to their plans and adapt to their schedules and operation. Actually, citizenship is a necessary evil, they bother a little and we must try to avoid them when they cannot be convinced that the municipal proposals are logical and adequate." Fernardo Pindado, "La participación no se improvisa," Revista de estudios locales, no. 87 (December 2005): 1-18.
} 
to try to overcome "the designer-non-designer gap," "the reality-representation gap" and "the designer-user gap" which are some of the conditions that are used to question the participatory processes in the field of urban design. ${ }^{11}$

\subsection{Communication and dissemination}

Table 2. Communication and dissemination processes.

\begin{tabular}{|c|c|}
\hline \multicolumn{2}{|c|}{ Summary of the communication and dissemination processes } \\
\hline Communication and Dissemination & Media \\
\hline Communication of the workshop results & $\begin{array}{ll}\text { - } & \text { Exhibition(s) } \\
\text { - } & \text { Explanation to the citizens } \\
\text { - } & \text { Popular University } \\
\text { - } & \text { Giving visibility to the process in the } \\
& \text { media }\end{array}$ \\
\hline Dissemination (abroad) & $\begin{array}{ll}\text { - } & \text { Papers } \\
\text { - } & \text { Books } \\
\text { - } & \text { CD-ROM }\end{array}$ \\
\hline
\end{tabular}

Source: own study.

Communication of the results. The normal procedure supposes a technical and political evaluation and appraisal of the civic participation processes. The methodology we propose outlines the need the community to evaluate the workshop, since we understand the project is not completed if it is not referred back to the citizens to whom it is addressed. In this sense, it is essential in order to fulfil the objectives 1,2 , and 4 (in smaller measure the 3 ), to revert the work to the citizens. Then, it is necessary to develop a next phase for the workshop in which the participants outline, study and design the communication acts with the rest of the citizenship. We believe that the follow up process in Sant Adrià, constitutes a good model that allows, with slight retouches in function of each case, to establish the basic rules of the communication system within the city, with the citizens, while empowering the active participation of those who want to be involved in the final phase of the project.

Exhibition(s). An exhibition gathers up the contents, phases, processes, aspects and essential proposals of the workshop (fig. 3-8). The exhibition was presented in two different formats.

One was the traditional form that allowed the exhibition to be shown to the entirety of the city territory, bringing the proposals to all the citizens. This exhibition form was be accompanied by media supports that allowed the use of the Information Technology: CD-ROM and Web pages (when possible).

${ }^{11}$ Matthew Carmona et al., Public Places - Urban Spaces. The Dimensions of Urban Design (Oxford: Architectural Press, 2003). 

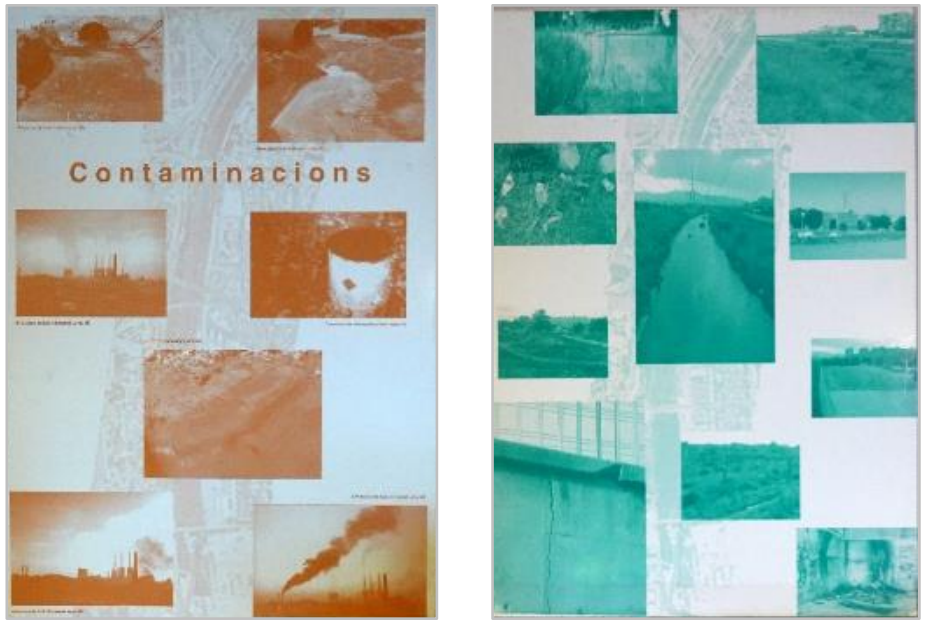

Segona tase:
Detecoid i prioritznció de neoessàats sctuals a Sent Adrâ do Detecoid i priorizació ce neoess
Besos sepans eis participants
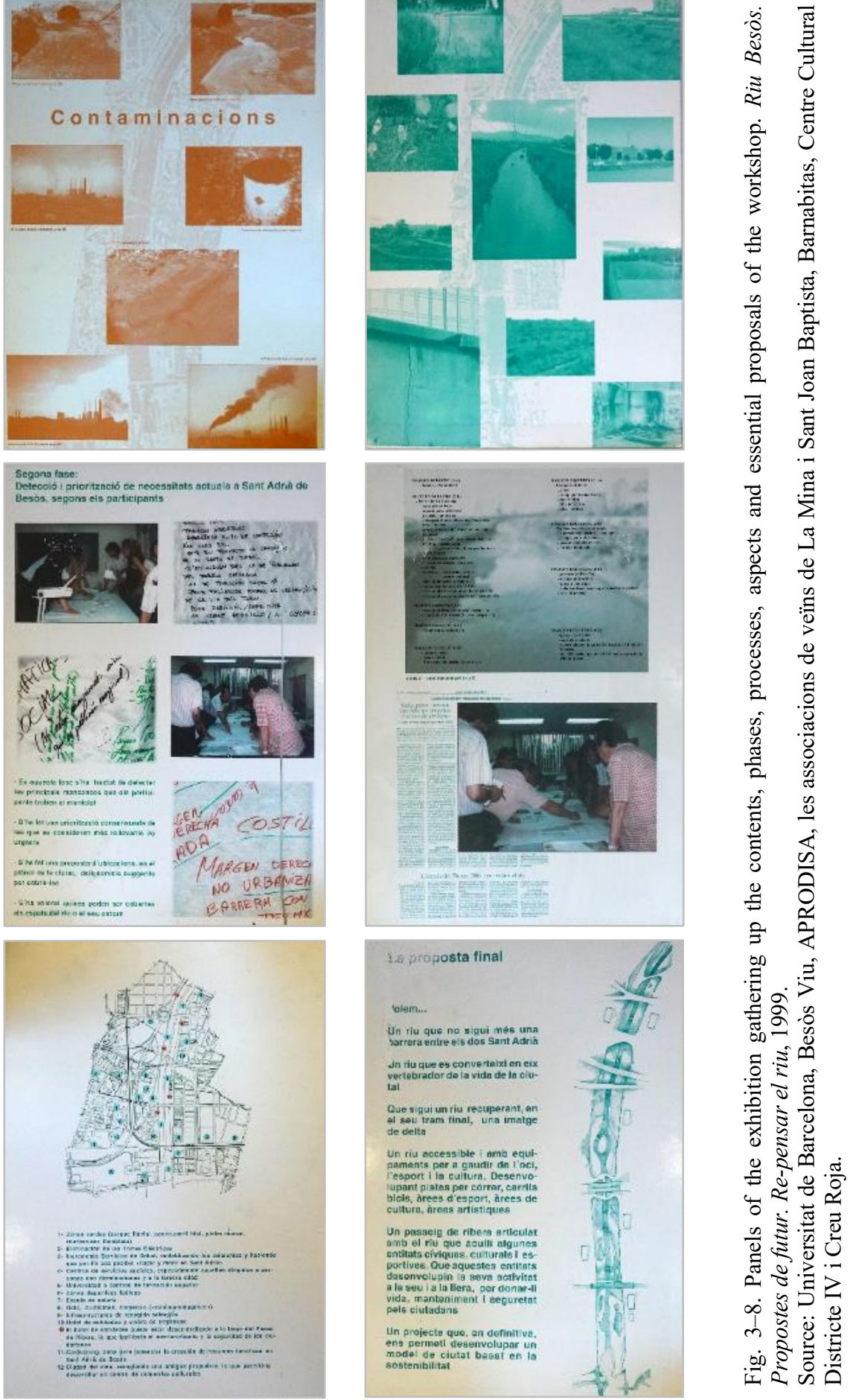
Participation can be boosted in a classic way through the exhibitions. That is to say through questionnaires that capture the opinion of the visitors. If it is possible, also, that these questionnaires can have an electronic format that will make it possible for other sector of the population to participate with their suggestions.

Explanation to the citizens. The exhibition can gather and document faithfully the development of the whole project but it is necessary, to facilitate the participation, that the members of the workshop develop an intense contact with the rest of the associative "fabric" that has not participated directly in the workshop, by means of organising work sessions with these groups to explain the experience "from the inside," that is to say, to present the experience as being centred more in the participative and working aspects than in the formal aspects of the results that the exhibition takes charge of developing. In these sessions it is very important to pick up the contributions, suggestions, comments and criticisms that the proposals of the workshop raised (Popular University $^{12}$ ).

Giving visibility to the process. The communication design also implies "media management." The workshop must be able to energise the local media (newspapers, magazines, bulletins, etc.) so that they inform about the workshop, its results and about the exhibition. This task is more complex if it should be applied to media of national coverage and, in this case, the participation of the City council can be decisive in working to promote the visibility of the workshop.

Dissemination. As for an academic and research team, the experience carried out was based on the usual procedures in the university context, in parallel with the dissemination in the local press. ${ }^{13}$

\footnotetext{
${ }^{12}$ In this project we started one of the practices that has remained helpful in the others: the approach of the "University" to the "Society" (the neighbourhoods), through the organization of seminars, conferences and the holding of International Conferences in those neighbourhoods where we were working. Through these procedures, the quality of the process is guaranteed since the criteria of Reliability, Responsiveness and Access are met; Public Management and Governance, ed. Tony Bovaird and Elke Löffer (London: Routledge, 2003).

${ }^{13}$ Antoni Remesar and Enric Pol, Repensar el río. Taller de Participación ciudadana "Usos Sociales del río Besòs" (Barcelona: Publicacions i Edicions de la Universitat de Barcelona, 1999), CD-ROM; Antoni Remesar and Enric Pol, "Civic Participation Workshops in Sant Adrià de Besòs: A Creative Methodology," in Locality, Regeneration \& Divers[c]ities, ed. Sarah Bennett and John Butler (Bristol: Intellect, 2000), 153-158.
} 
2. RESULTS AND LEARNINGS FROM THE PARTICIPATORY PROCESS

Table 3. Learnings of the process.

\begin{tabular}{|c|c|}
\hline \multicolumn{2}{|c|}{ Summary of the results and learnings of the process } \\
\hline $\begin{array}{l}\text { Outcomes: } \\
\text { Social, } \\
\text { Environmental } \\
\text { and Political } \\
\text { Empowerment }\end{array}$ & $\begin{array}{l}\text { - The need to overpass the "the designer-non-designer," } \\
\text { "the reality-representation" and "the designer-user" gaps } \\
\text { - The possibility of bolstering the organizational initiatives } \\
\text { of the participants } \\
\text { - The possibility of bolstering the citizens' capability } \\
\text { for a strategic political action }\end{array}$ \\
\hline Learnings & 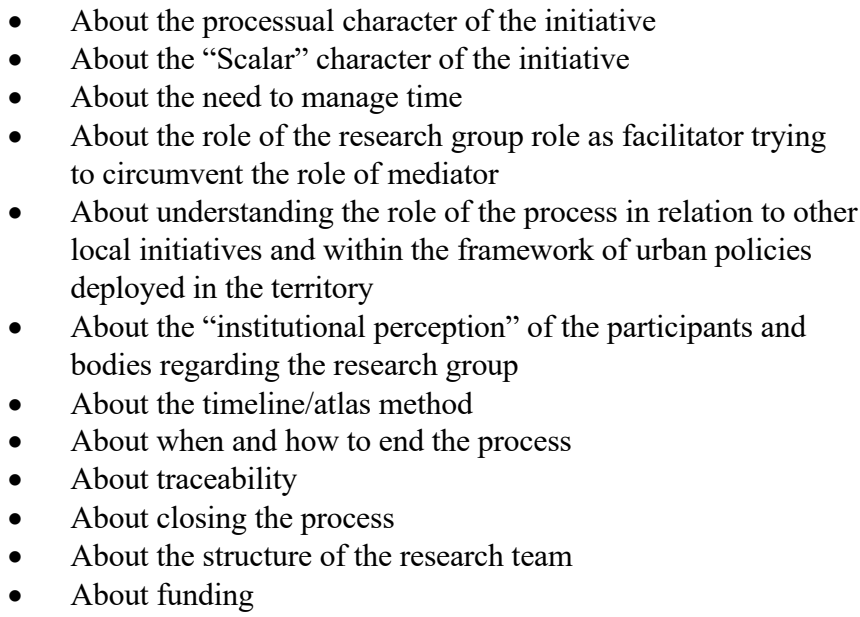 \\
\hline
\end{tabular}

Source: own study.

\subsection{Outcomes}

We can group the outcomes ${ }^{14}$ of the process into two packages. The first refers to the objective "empowerment of citizens." [1] Empowerment of the neighbours regarding certain technical particularities regarding the design of the public space, aiding to overpass the "the designer-non-designer," "the reality-representation" and "the designer-user" gaps. [2] Empowerment of the neighbours by formalizing a new civic association, Besòs 2004, in charge of monitoring and supervising the development of the river recovery project.

\footnotetext{
${ }^{14}$ We use this term in the sense proposed by Bovair, as a benefit or benefits obtained in the development of the process. The different levels of empowerment as outcomes of the process create "values": environmental value, social value and political value; Tony Bovaird, "Evaluation of Public Projects and Services," (Seminar at University of Barcelona, 2010).
} 
The second package refers to the empowerment of citizens for a strategic political action. Specifically, the formal arguments of the project were used as the basis for the allegations presented by different civic associations of Sant Adrià and the City Council, against the project of territorial remodelling presented by Barcelona Regional. ${ }^{15}$ These allegations stopped the development of the idea of channelling the final stretch of the river for sporting uses associated with the new marina. Today the recovery of the river ends with a small delta that is used again by migratory birds that traditionally used it.
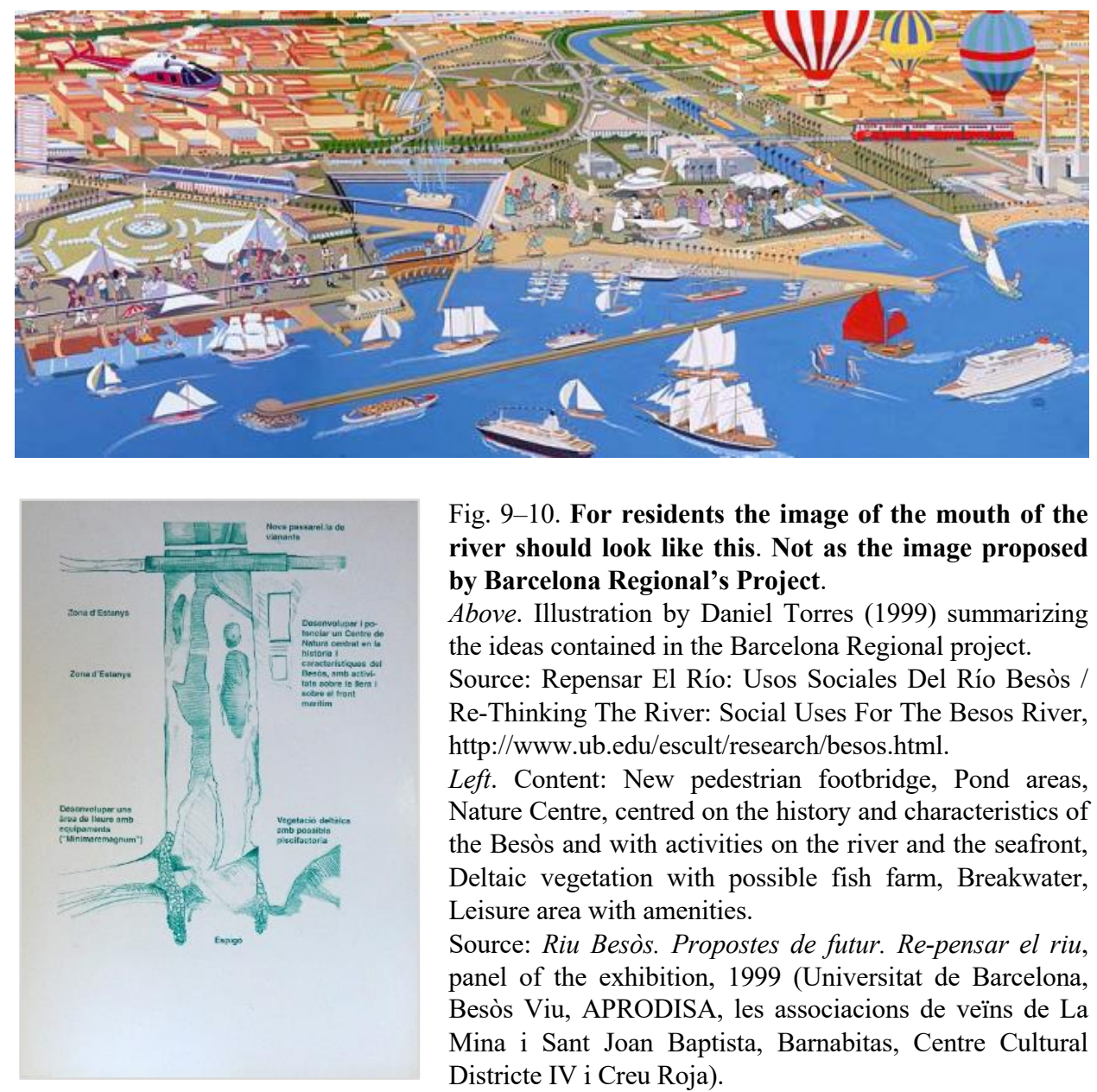

Fig. 9-10. For residents the image of the mouth of the river should look like this. Not as the image proposed by Barcelona Regional's Project.

Above. Illustration by Daniel Torres (1999) summarizing the ideas contained in the Barcelona Regional project.

Source: Repensar El Río: Usos Sociales Del Río Besòs / Re-Thinking The River: Social Uses For The Besos River, http://www.ub.edu/escult/research/besos.html.

Left. Content: New pedestrian footbridge, Pond areas, Nature Centre, centred on the history and characteristics of the Besòs and with activities on the river and the seafront, Deltaic vegetation with possible fish farm, Breakwater, Leisure area with amenities.

Source: Riu Besòs. Propostes de futur. Re-pensar el riu, panel of the exhibition, 1999 (Universitat de Barcelona, Besòs Viu, APRODISA, les associacions de veïns de La Mina i Sant Joan Baptista, Barnabitas, Centre Cultural Districte IV i Creu Roja).

${ }^{15}$ Cf. Barcelona Nous Projectes/Barcelona New Projects; Modificació del PGM en el sector del Front Litoral i Marge dret del riu Besòs. Text refós, Barcelona Regional, Registre Planejament urbanistic de Catalunya, (Barcelona: Ajuntament de Barcelona, 2000), http://ptop.gencat. cat/rpucportal/AppJava/cercaExpedient.do?reqCode=veureDocument\&codintExp=100045\&fromP age $=$ load 
2.2. What we learned from the process?

Managing processes of people's empowerment has become one of the great challenges of representative democracies, both consolidated and emerging. ${ }^{16}$ It is obvious that, as already said continuously since the mid-sixties of the last century, we must understand the civic participation projects from a processual, scalar and time perspective.

Processual, by the fact that they overlap each other, tie in with political cycles, traversing different instances of everyday life and, above all, because a process leads to another in a logical and dynamic spiral considering that when a participatory process is launched, it is known when it starts but it is difficult to know when it ends. The imponderables, the collateral effects and their management are very difficult to predict.

Scalar, because processes can affect daily life at its various scales. The management of these participatory processes is linked to a territorial scale (street, neighbourhood, district, city, region), not always limited to the area of the territory to which the project is addressed. So, the relationship between the global (understood many times as regional) and the local is fundamental. At the same time, participatory processes are framed in local politics, with a capital P. This means that these processes can interfere with the legal procedures of the representative democracy and its management is not, in most cases, easy or calm.

Time, participatory processes consume a huge amount of time, a resource that in the current context is highly appreciated. Thus, in the participatory processes we find ourselves with the following paradox: we need a lot of time and we have little time. A lot and little that affects all the participating actors. [1] To citizens because they must "subtract" the little time they have for rest and for what we can call "family conciliation." [2] To the administration and technicians because, within the framework of urban policies, time management of participation processes "clashes" with time management of administrative processes, political processes, urban processes etc. That is why, from this understanding of participation, we must know how to manage time and, as a consequence, the procedures - methods that will allow us to achieve results, but, always, focusing on the internal process.

\footnotetext{
${ }^{16}$ Sara Kindon, et al., ed., Participatory Action Research Approaches and Methods: Connecting People, Participation and Place (London: Routledge, 2007); Linda Nicholson, "Civic Participation in Public Policy-Making: A Literature Review," Research Findings, no. 14 (2005): 1-4; Sanoff, Community Participation; Bovaird and Löffer, Public Management and Governance; Universal Declaration of Emerging Human Rights (Barcelona: Institut de Drets Humans de Catalunya, 2009), http://www2.world-governance.org/IMG/pdf_DUDHE-2.pdf; ELSE CITIES, "New Urban Governance: Urban complexity and institutional capacities of cities," accessed in December, 2017, https://lsecities.net/objects/research-projects/new-urban-governance; Jon Pierre, "Rethinking Comparative Urban Politics: From Urban Regime Theory to Urban Governance?," posted August 15, 2011, http://dx.doi.org/10.2139/ssrn.1909759
} 
A first consideration: we should ask ourselves, what is our purpose? When we embark on the organization and development of a participatory citizen process? Simplifying the answers are twofold. Or, through our activity, we tend to legitimize government action through the process, while we can detect, among the citizens, "symptoms" of discomfort referred to certain actions. Or, the purpose is [1] to empower a given population, understanding empowerment as the capability to assume and the ability to solve a problem, while [2] empowering this people to intervene directly - that is, politically - in the decision-making process that will lead to the effective solution of a problem.

This analysis immediately raises two "different temporalities" One slow, another faster, at the same time as it determines "process stages" that must be organized in a continuum. To qualify (one of the key elements of empowerment) is to give tools - conceptual, methodological, instrumental, linguistic, etc. Giving tools of this type is not achieved in a short time, considering that we are handling very limited physical temporalities. Giving tools requires "time," surely a long time.

\subsection{Facilitation vs mediation}

In this context, to provide tools, supposes, also, a radical change in the game of roles of the different participating actors, especially that of the "technicians." Normally the technicians (community, educators, town planners...) deploy a role of mediators between the population and the administration in charge of the process. The performance of his role is very technical, not to say technocratic. However, in a participatory process the technician should transpose his/her role as mediator, tending to a role of facilitator. ${ }^{17}$

What would a facilitator be? A technically trained person who, in a participatory process, has as mission the accompaniment in the process and the training - contribution of instrumental, conceptual, methodological resources etc. - thanks to which participants will adopt a self-directed attitude and a greater degree of autonomy ${ }^{18}$ in the defence of what they considered best for the city, trying to end the process with operational proposals and not just with either a wish list or a list of complains.

In short, a "facilitator" would be who is able to introduce a qualitative leap in the argumentation structure and development of a given problem, so, surpassing the topical approaches and solutions. Facilitation work takes time but also

\footnotetext{
${ }^{17}$ Xavier Salas, "L'artista com a facilitador en els processos de participació ciutadana: el cas Baró de Viver a Barcelona," (PhD diss., Universitat de Barcelona, 2015), https:/www.tdx.cat/handle/ 10803/308505; John Heron, The complete facilitator's handbook (London: Kogan Page, 1999).

${ }^{18}$ Heron, The complete facilitator's handbook; John Heron, Dimensions of Facilitator Style (London: University of Surrey - University of London, 1977).
} 
a change of methodological devices for facilitation. The usual methods of consultation do not seem to be appropriate, nor are certain work schemes such as Participatory Intervention Nuclei ${ }^{19}$ (PIN), which are far from the real possibilities in many processes.

\subsection{Participatory process vs. local or regional policies}

A participatory process in which our team adopts the role of facilitator and concludes with operational proposals to solve the initial problem or issue, must contemplate the collision between the process and municipal or regional policies. This was the case of the process we analyse. The conclusions of the citizens came into confrontation with the political interests of the Besòs Consortium (Barcelona and Sant Adrià) reflected in the Barcelona Regional project for the last stretch of the river. In the case of Sant Adrià municipality, this confrontation supposed, in addition, the tacit confrontation within the municipal government, since part of the political parties that supported the government assumed the neighbour's theses bring the risk for the majority party to enter in confrontation with its own citizenship.

Furthermore, in the context of convulsive relations between the metropolitan authorities and the government of the Generalitat, the process involved opening a conceptual gap in the monolithic metropolitan strategic programme focused on what was called "Barcelona's New Projects." 20

\subsection{Institutional role of the research team}

For neighbours, the research team is not the CR POLIS. It's the University. That is, the participants in the process grant the research team the role of representative of an institution, and metonymically identify the Research Centre with the University Institution. We are not a charity, nor an NGO, nor a group of "political or neighbourhood activists." In all the processes that we have carried out, this fact is repeated: CR POLIS IS THE UNIVERSITY. And being "the university" gives us the "values" of credibility, neutrality and independence for the management of the process. Curiously, when there is

\footnotetext{
19 "The PINs are a group formed of people chosen at random and released from their daily work for a limited time, on a remunerated basis, to seek solutions to pre-established problems, being assisted by responsible organizers;" Peter C. Dienel and Hans Harms, Repensar la democracia: los Núcleos de Intervención Participativa (Barcelona: Ediciones del Serbal, 2000).

${ }^{20}$ Barcelona Nous Projectes/Barcelona New Projects; Horacio Capel, El Modelo Barcelona: un exámen crítico (Barcelona: Ediciones del Serbal, 2005); Jordi Borja, Luces y sombras del urbanismo de Barcelona (Barcelona: Editorial UOC, 2009).
} 
formal agreement for the development of participatory processes, the local administration also adopts this imaginary. Maybe this was one of the most relevant learnings.

That is why the research team must be aware of its role and actions. For example, we learned that we could not parachute students in the process without adequate training and, above all, without the necessary engagement. It is well known that many academic or research teams to develop field work move undergraduate students over the territory. However, in our context, a very sensitive context, it seems unlikely to use this strategy.

We learned also that, on our part, the only "appropriation" of the process should be an academic appropriation reflected in the dissemination mechanisms of the project (papers, papers, books, exhibitions) always recognizing the neighbours as "co-authors" of the deliverables. But, above all, we learned the obligation to structure our demands for public research funding in relationship to the processes we were developing or those we had in our portfolio.

\subsection{The importance of timeline / atlas procedure}

The structure based on the analysis of the past and the present and supported by the use of visual documents, led us to develop a working procedure that is inspired, on the one hand, by the communicative schemes of the CD-ROMs, specially that in the Encarta ${ }^{21}$ and games that were developed at that time and that made possible the access to a "timeline" of the respective contents, which allowed its study from the temporal perspective, and on the other hand, by the idea that Ildefons Cerdà ${ }^{22}$ used first to explain his references to the cities on which he based his project for the extension of Barcelona, and that later we found in the works by Warburg for his "Mnemosyne Atlas" ${ }^{23}$ and, even, in the project of the "Imaginary Museum" by André Malraux. ${ }^{24}$

\footnotetext{
${ }^{21}$ Microsoft Encarta was a digital multimedia encyclopaedia published by Microsoft Corporation between 1993 and 2009.

${ }^{22}$ Ildefons Cerdà, "Teoría de la Construcción de las ciudades aplicada al proyecto de reforma y Ensanche de Barcelona," in Teoría de la construcción de las ciudades. Cerdà/Barcelona, vol. 1, ed. Busquets, Joan (Madrid: MAP - Ajuntament de Barcelona, 1991); Antoni Remesar and Salvador García Fortes, "Building the New Barcelona. The importance of the survey on common architecture in the Cerda's Project," in To and Fro, Modernism and Vernacular Architecture, ed. Joana Cunha Leal, et al., (Porto: CEAA, 2013), 129-152.

${ }^{23}$ Christopher D. Johnson, "About the Mnemosyne Atlas," The Warburg Institute, Cornell University, accessed December 2016, https://warburg.library.cornell.edu/about

${ }^{24}$ André Malraux, O Museu Imaginário (Lisboa: Ediçoes 70, 2000).
} 

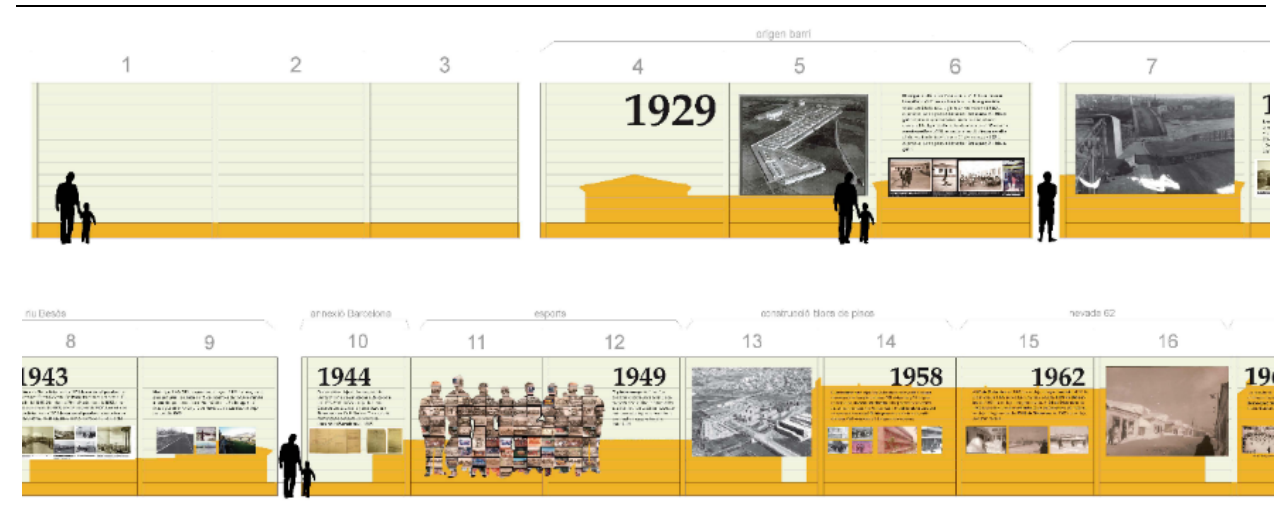

Fig. 11. Graphical outline of the proposal for the Mural of Remembrance in Baró de Viver (2011) based on the procedure timeline/atlas (details).

Source: Centre de Recerca Polis, Universitat de Barcelona.

This work plan was decisive for the organization of the "Remembrance Mural" (2011) in Baró de Viver, one of the results of the participatory process developed in this Barcelona neighbourhood and, for organizing the information for the ongoing project "Remembrance Spatial System" in Bon Pastor, too in Barcelona.

\subsection{Traceability}

Traceability can be considered as the ability to verify the history, location, or application of an item by means of documented recorded identification. In this first process the traceability is organized a posteriori. However, both the gradual usability of information technologies and the training of the team allowed for the incorporation of traceability in parallel with the development of the process (Table 4).

Table 4. Participatory process and traceability.

\begin{tabular}{|l|l|}
\hline \multicolumn{1}{|c|}{$\begin{array}{c}\text { PARTICIPATORY } \\
\text { PROCESS }\end{array}$} & \multicolumn{1}{c|}{ TRACEABILITY } \\
\hline $\begin{array}{l}\text { Social Uses of the Besòs } \\
\text { River }\end{array}$ & $\begin{array}{l}\text { A posteriori. CD-ROM + inclusion in the website of the Centre } \\
\text { http://www.ub.edu/escult/research/besos.html }\end{array}$ \\
\hline Mapping La Mina & $\begin{array}{l}\text { A posteriori. Specific website } \\
\text { http://www.ub.edu/escult/mina/cartografies/html/index.html }\end{array}$ \\
\hline Baró de Viver & $\begin{array}{l}\text { Parallel to the process. Web site of the Centre. } \\
\text { http://www.ub.edu/escult/participacio/index_baro.html }\end{array}$ \\
\hline Bon Pastor & $\begin{array}{l}\text { Parallel to the process. Blog of the process } \\
\text { https://femlamemoriadelbonpastor.wordpress.com/proceso-parti } \\
\text { cipativo/ }\end{array}$ \\
\hline
\end{tabular}

Source: own study. 


\subsection{Closing the process}

The participatory process we are analysing faced two distorting situations. The first, as mentioned before, was the project by Barcelona Regional. This presentation, pending the approval of the urban plan that would make it possible, meant diverting the attention of the participants towards the preparation of the allegations foreseen by legislation. The second interference in the process, was caused by the electoral calendar. Indeed, the last steps in the work of the group coincided with the beginning of the electoral campaign for the 1999 municipal elections.

In any case, the participants considered that the work was coming to an end and that its continuity, that is to say the evaluation of its implementation, depended on a new negotiation with the City Council elevating the conclusions to a technical discussion process, both with the politicians and with the City Planning technicians. For this reason, a last meeting of the working group was held in which the director of the Research Centre briefly explained the development and achievements of the participatory process and stated that the Research Centre concluded the process, simply waiting to finalize the edition of the CD-ROM that served as means of diffusion and that the City Council would edit. As in any closing of the activity of a group, the closing was emotional and did not lack moments in which the group claimed that the Centre would continue working, in one way or another. However, the results of the municipal elections, modified the forces correlation in the City Council and, the new board closed the working process.

\subsection{The team and its structure}

An important lesson learned from this closure was the observation that the structure of the research team working in the field should have certain characteristics. It is well known that in group dynamics, as intense as those developed in the participatory process, from time to time it is pertinent to assert an external "principle of authority" to elucidate situations that can lead the research team to an overly personal implication and, thus, in danger of losing its ability to facilitation. If the whole team was in the field, a significant problem of "backing up" to their activity could be glimpsed.

That is why, as a conclusion of the work, a layered organizational scheme was proposed. The research team on the ground would have complete freedom of interfacing with the working group, but at the time when could appear some kind of conflict that might distract participants to continue with their objectives, could resort to the support of a centre's "outside-of-the process" team. 


\subsection{Funding}

Research needs funding. The work process was based on the existence of sufficient funding, by the Ministry of Science and Technology of Spain, to cover the costs of carrying out the process. In parallel, the Centre and the City Council of Sant Adrià de Besòs, signed a collaboration agreement involving an economic contribution from the City Council, mainly to cover expenses related to the dissemination of the Project (exhibition, CD-ROM). This scheme has been maintained over time in the development of the participatory processes. Schematically:

Table 5. The development of the participatory processes.

\begin{tabular}{|l|c|c|c|c|l|l|}
\hline & $\begin{array}{l}\text { Local } \\
\text { Authority } \\
\text { Agreement(s) }\end{array}$ & $\begin{array}{l}\text { State } \\
\text { Funding } \\
\text { (Micinn) }\end{array}$ & $\begin{array}{l}\text { Regional } \\
\text { Funding } \\
\text { (Agaur) }\end{array}$ & $\begin{array}{l}\text { E.U } \\
\text { Funding } \\
\text { (urban) }\end{array}$ & $\begin{array}{l}\text { University } \\
\text { of } \\
\text { Barcelona } \\
\text { Funding }\end{array}$ & $\begin{array}{l}\text { International } \\
\text { Agencies } \\
\text { fellowships } \\
\text { funding }\end{array}$ \\
\hline $\begin{array}{l}\text { Repensar el } \\
\text { río. Usos } \\
\begin{array}{l}\text { Sociales del } \\
\text { Río Besòs }\end{array}\end{array}$ & $\mathrm{x}$ & $\mathrm{x}$ & & & & \\
\hline $\begin{array}{l}\text { Mapping } \\
\text { La Mina }\end{array}$ & $\mathrm{x}$ & $\mathrm{x}$ & $\mathrm{x}$ & $\mathrm{x}$ & $\mathrm{x}$ & \\
\hline Baró de Viver & $\mathrm{x}$ & $\mathrm{x}$ & $\mathrm{x}$ & & & $\mathrm{x}$ \\
\hline Bon Pastor & $\mathrm{x}$ & $\mathrm{x}$ & & & $\mathrm{x}$ & \\
\hline
\end{tabular}

Source: own study.

In addition, the State, Regional and University of Barcelona funding has allowed the incorporation of researchers with a contract for the development of doctoral theses. ${ }^{25}$

\subsection{And how has it conditioned our subsequent projects?}

This long analysis of our first citizen participation project is fundamental because it lays the foundation for our approach to citizen participation and, by extension, to the "bottom-up" governance processes. ${ }^{26}$

\footnotetext{
${ }^{25}$ Nuria Ricart, "Cartografies de La Mina: Art, espai públic, participació ciutadana," (PhD diss., Universitat de Barcelona, 2009), http://hdl.handle.net/10803/1549; Salas, "L'artista com a facilitador;" Samuel Padilla, "Producción de Espacio Público [X] Participación Ciudadana. El proyecto de espacio público resultado de procesos de participación ciudadana" (PhD diss., Universitat de Barcelona, 2015), http://tdx.cat/handle/10803/309288; Ana Júlia Pinto, "Coesão urbana: o papel das redes de espaço público" (PhD diss., Universitat de Barcelona, 2015), http://hdl.handle.net/ 10803/320186; Danae Esparza, Barcelona a ras de suelo (Barcelona: Edicions Universitat Barcelona, 2017); Marien Ríos Díaz, "¿Hacer Ciudad? Barcelona, la construcción del paisaje, 1929-1973” (PhD diss., Universitat de Barcelona, 2017), http://hdl.handle.net/10803/481954
} 


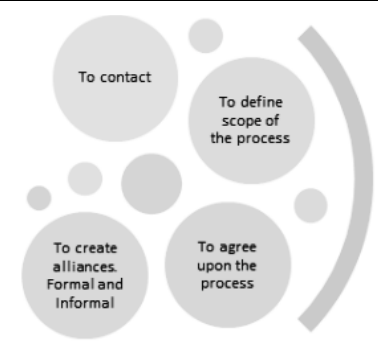

Stage 1

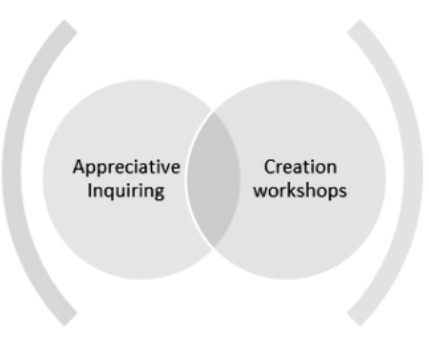

Stage 2

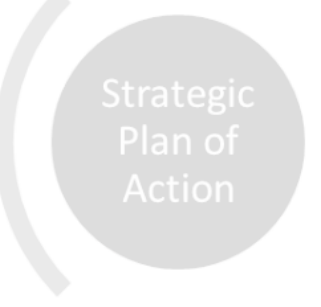

Stage 3

Fig. 12. Outline of the phases of the participatory processes.

Source: Centre de Recerca Polis, Universitat de Barcelona.

As with most urban issues, generalizations are difficult, given that each process, each project, is strongly conditioned by the context (social, political, temporal) in which it occurs. However, the scheme (fig. 12) accurately describes the development of the processes. The subsequent processes have been based on the lessons learned from the project on the Besòs river. In all of them, Participatory Action Research (PAR) strategy ${ }^{27}$ was adopted. This strategy is based in abiding respect for people's knowledge and for their ability to understand and address the issues confronting them and their communities, with the aim of provide people with the support and resources to do things, while facilitating facing the challenges of change and the integration of theory and practice. We assume the criticism of the procedure: it is a localist method and difficult to apply in processes that imply a broad social change. As we mentioned earlier, the "scale" of the processes is fundamental and therefore, the definition of our work focuses on the scale of the neighbourhood (cf. fig. 13-16). Other strategies will be necessary for the implementation of participatory processes at the city or regional level, as the EASW (European Awareness Scenario Workshops).

${ }^{26}$ Bovaird and Löffer, Public Management and Governance; Forum for a New World Governance 2002; Pierre, "Rethinking Comparative Urban Politics;" ELSE CITIES, "New Urban Governance;" UN-Habitat, "Urban Governance Index (UGI). A Tool to Measure Progress in Achieving Good Urban Governance," UN-Habitat. For a Better Urban Future, 1999, http://mirror.unhabitat.org/down loads/docs/2232_80907_UGIndex.doc; Marc Pradel and Marisol García, ed., El momento de la ciudadanía. Innovación Social y Gobernanza Urbana (Madrid: La Catarata, 2018); Frank Moulaert, et al., ed., Can neighbourhoods save the city? Community development and social innovation (Abingdon: Routledge. Taylor \& Francis Group, 2010).

${ }^{27}$ Action research is a work in progress. "Action research rejects the notion of an objective, valuefree approach to knowledge generation in favour of an explicitly political, socially engaged, and democratic practice. [...] Hence the challenges of 'scaling up' participatory, action-oriented processes for social justice and meaningful change are similar whether we work in and through universities or development agencies. [...] a participatory, democratic process concerned with developing practical knowing in the pursuit of worthwhile human purposes, grounded in a participatory worldview which we believe is emerging at this historical moment. It seeks to bring together action and reflection, theory and practice, in participation with others, in the pursuit of practical solutions to issues of pressing concern to people, and more generally the flourishing of individual persons and their communities." Peter Reason and Hilary Bradbury, ed., Handbook of Action Research. Participative Inquiry and Practice (London: SAGE Publications, 2001). 


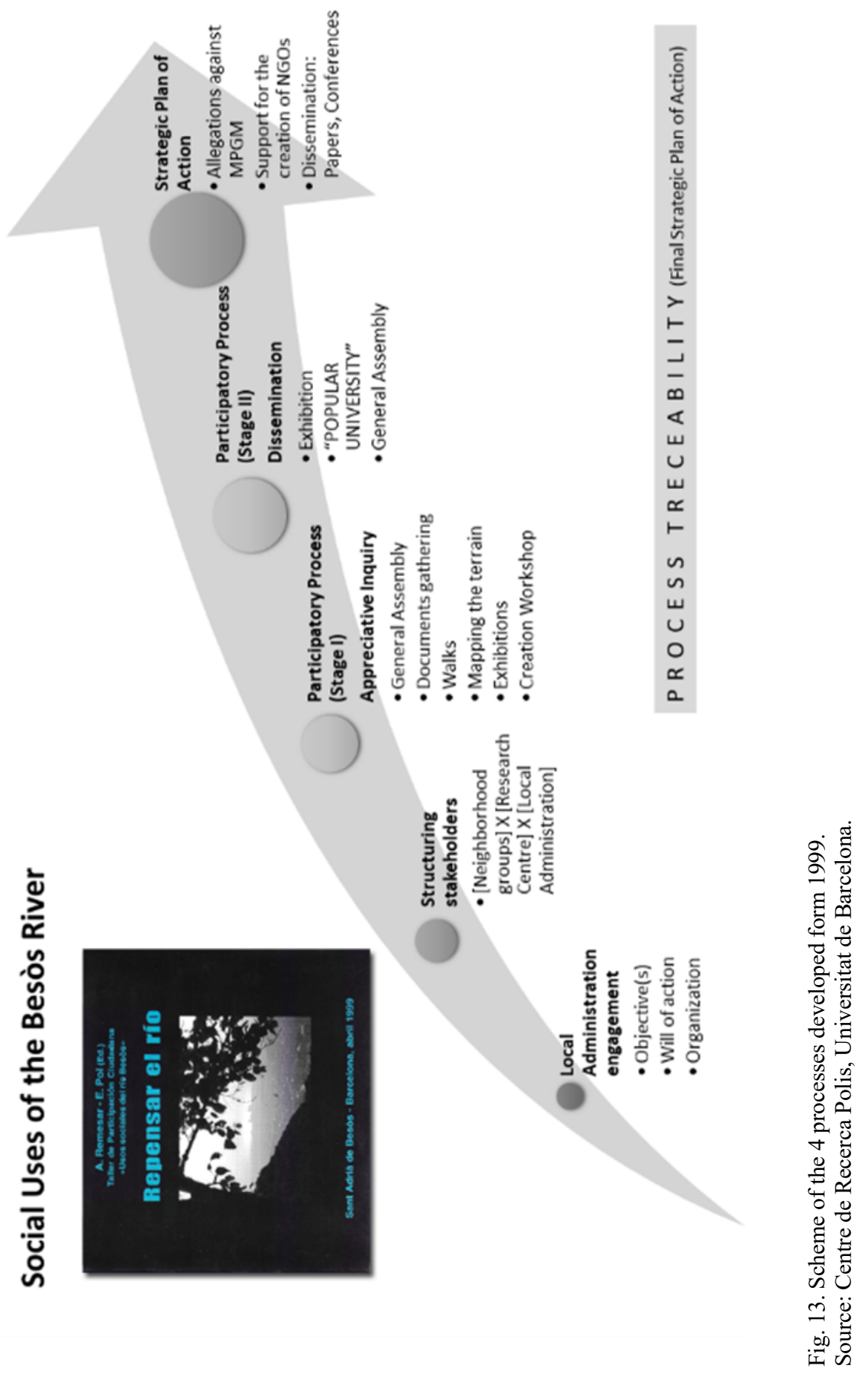




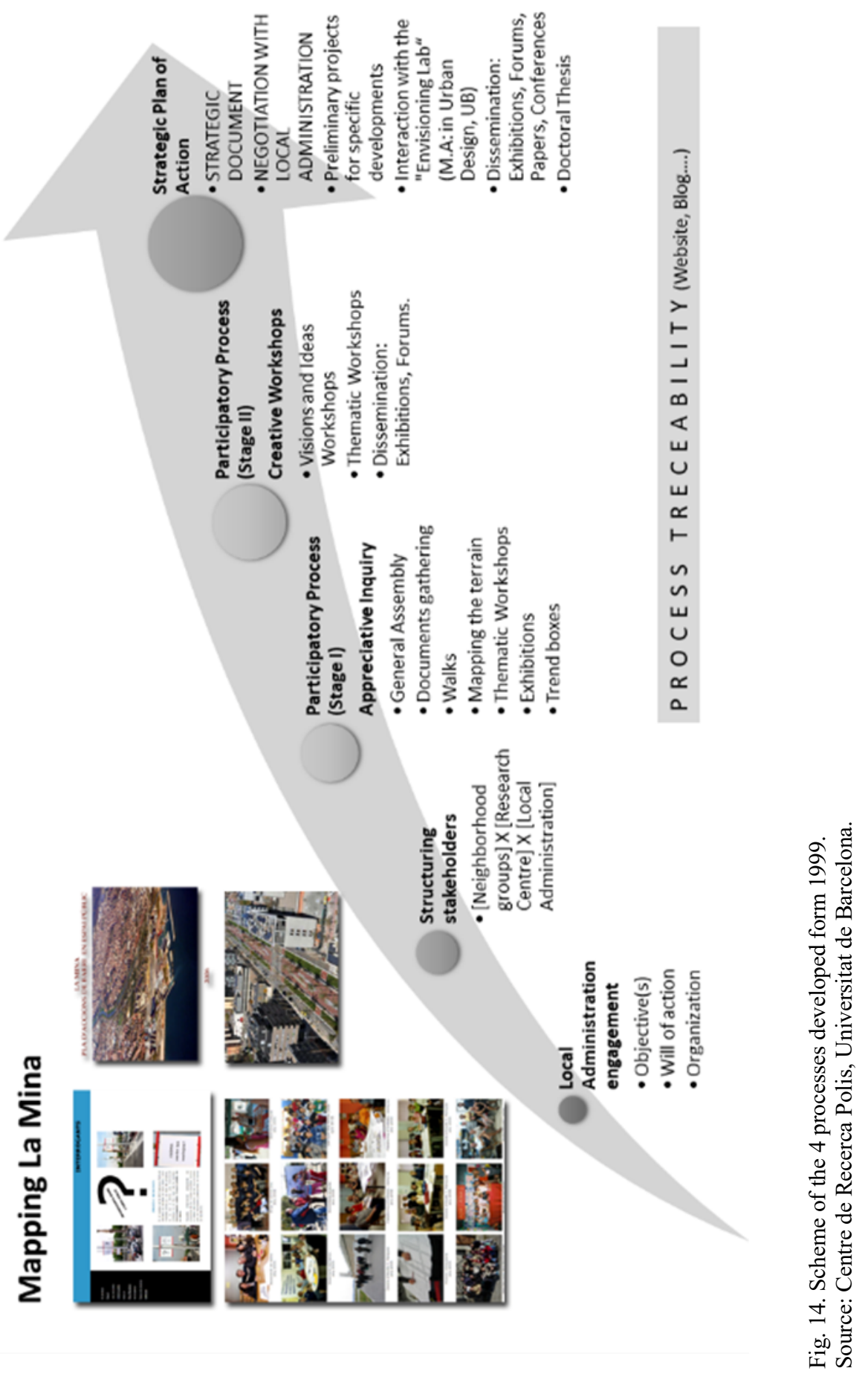



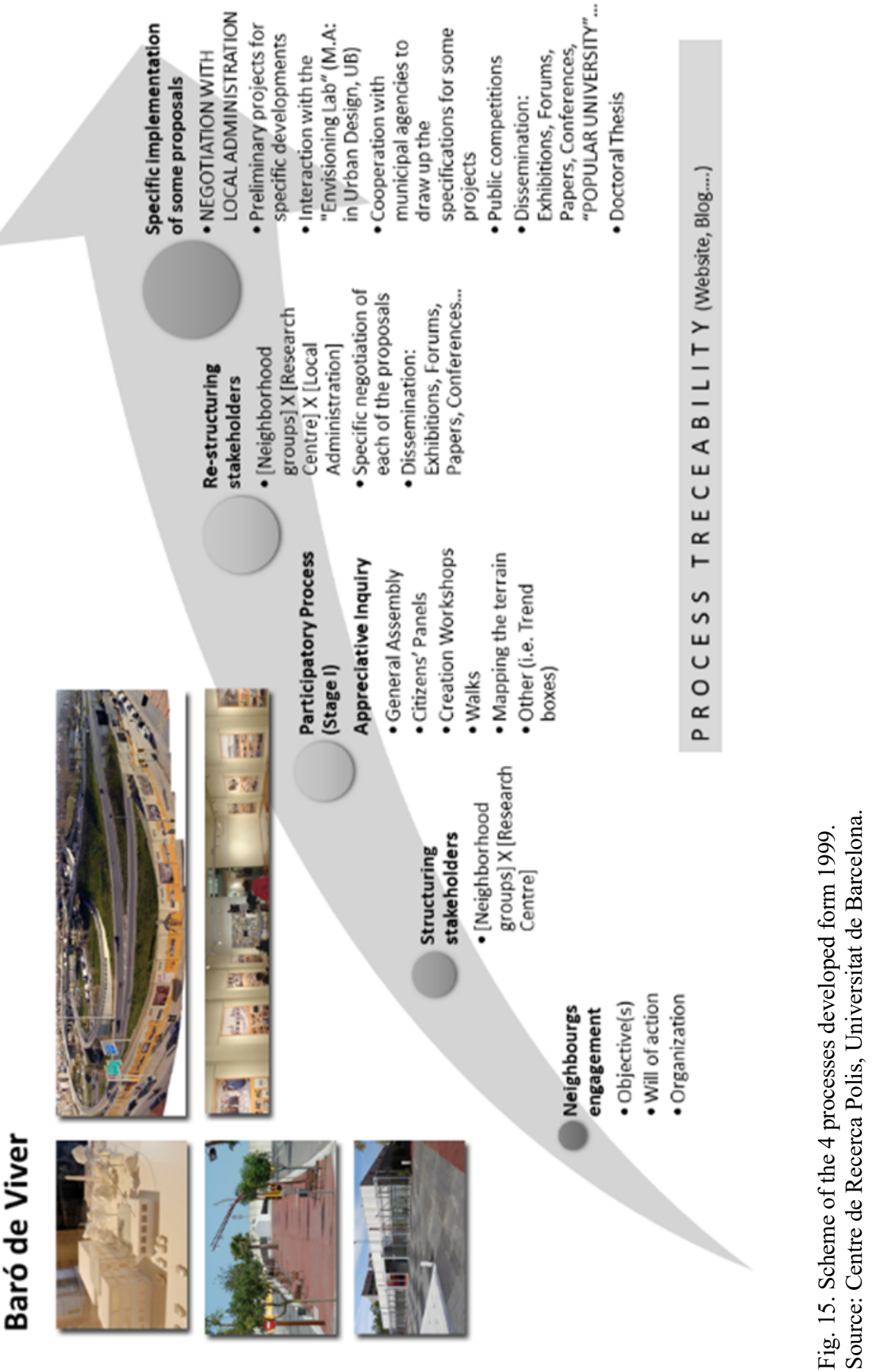

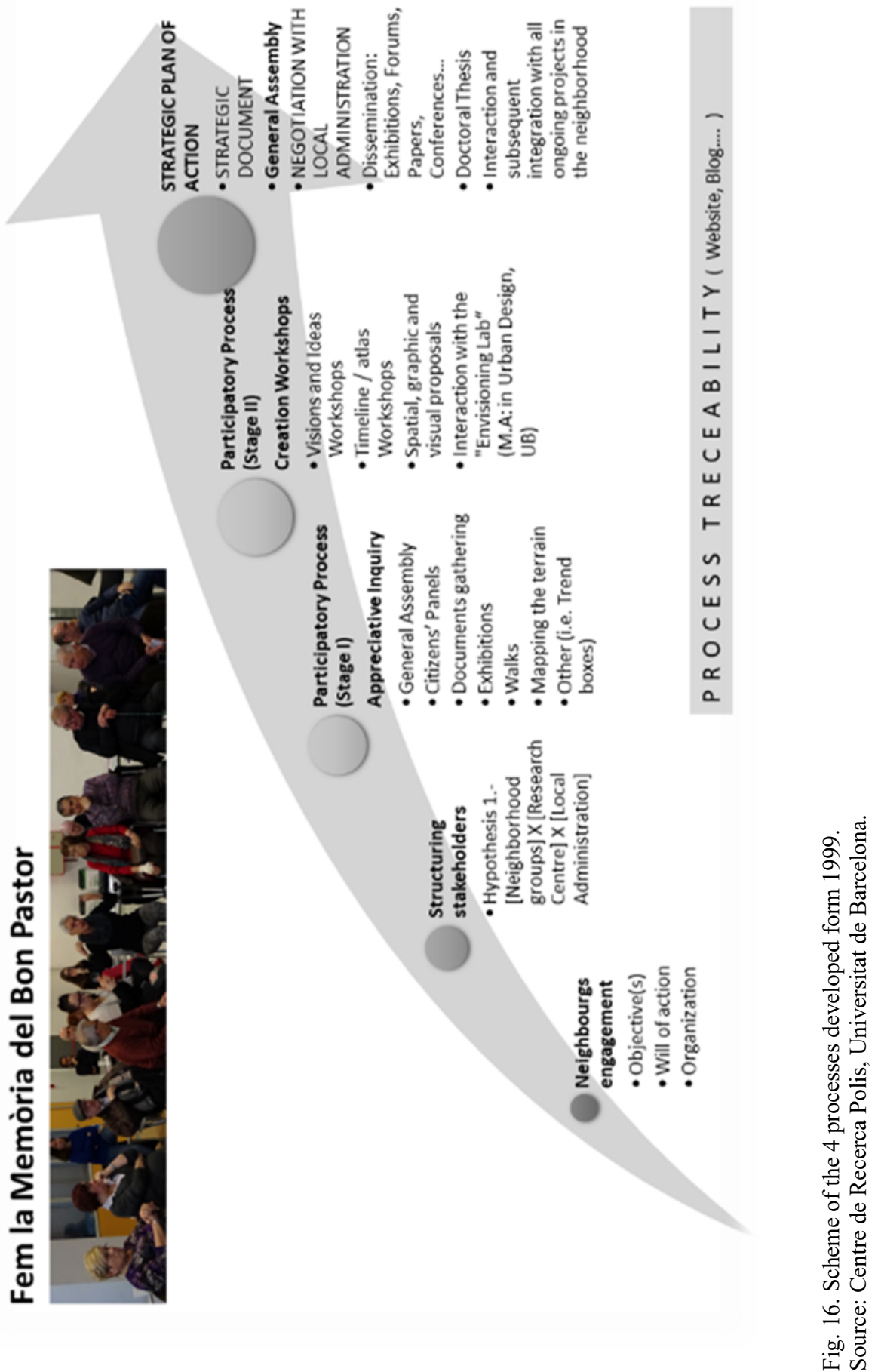


\section{Acknowledgments}

This work is part of the project HAR2017-88672-R, Ministerio de Ciencia e Innovación de España. With the support of the Agaur of the Generalitat de Catalunya (2017SGR1125) and the residents of Bon Pastor and the Sant Andreu district, Barcelona City Council.

\section{BIBLIOGRAPHY}

Angotty, Tom. "Advocacy and Community Planning: Past, Present and Future." Planners Network. The organisation of progressive planning, April 22, 2007. https://www.planne rsnetwork.org/2007/04/advocacy-and-community-planning-past-present-and-future/

Arnstein, Sherry R. "A Ladder Of Citizen Participation." Journal of the American Planning Association 35, no. 4 (July 1969): 216-224. https://doi.org/10.1080/01944366908977225

Barcelona Nous Projectes/Barcelona New Projects. Barcelona: Ajuntament de Barcelona, Barcelona Regional, 1999.

Barcelona Regional. Modificació del PGM en el sector del Front Litoral i Marge dret del riu Besòs. Text refós. Registre Planejament urbanistic de Catalunya. Barcelona: Ajuntament de Barcelona, 2000. http://ptop.gencat.cat/rpucportal/AppJava/cercaExpedient.do?reqCode=veu reDocument\&codintExp=100045\&fromPage=load

Borja, Jordi. Luces y sombras del urbanismo de Barcelona. Barcelona: Editorial UOC, 2009.

Bovaird, Tony. "Evaluation of Public Projects and Services." Seminar at University of Barcelona, 2010.

Bovaird, Tony, and Elke Löffer, eds. Public Management and Governance. London: Routledge, 2003.

Cantallops, Lluís, and Manuel Ribas, Estanislau Roca. "El pla del marge dret del Besòs a Sant Adrià." Papers. Regió Metropolitana de Barcelona: Territori, estratègies, planejament, no. 13 (1993): 49-64.

Capel, Horacio. El Modelo Barcelona: un exámen crítico. Barcelona: Ediciones del Serbal, 2005.

Carmona, Matthew, and Tim Heath, Taner Oc, Steve Tiesdell. Public Places - Urban Spaces. The Dimensions of Urban Design. Oxford: Architectural Press, 2003.

Cerdà, Ildefons. "Teoría de la Construcción de las ciudades aplicada al proyecto de reforma y Ensanche de Barcelona." In Teoría de la construcción de las ciudades. Cerdàl Barcelona. Vol. 1, edited by Joan Busquets. Madrid: MAP - Ajuntament de Barcelona, 1991.

Dienel, Peter, C., and Hans Harms. Repensar la democracia: los Núcleos de Intervención Participativa. Barcelona: Ediciones del Serbal, 2000.

ELSE CITIES. "New Urban Governance Urban complexity and institutional capacities of cities." Accessed in December, 2017. https://secities.net/objects/research-projects/new-urbangovernance

Esparza, Danae. Barcelona a ras de suelo. Vol. 17 of Comunicación Activa. Barcelona: Edicions Universitat Barcelona, 2017.

Heron, John. Dimensions of Facilitator Style. London: University of Surrey/University of London 1977.

- The complete facilitator's handbook. London: Kogan Page, 1999.

Johnson, Christopher, D. 2013. “About the Mnemosyne Atlas.” The Warburg Institute. Cornell University. Accessed in December 2016. https://warburg.library.cornell.edu/about

Kindon, Sara, and Rachel Pain, Mike Kesby, eds. Participatory Action Research Approaches and Methods: Connecting People, Participation and Place. London: Routledge, 2007.

Malraux, André. O Museu Imaginário. Lisboa: Ediçoes 70, 2000. 
Marchioni, Marco. Comunidad, participación y Desarrollo: Teoría y metodología de la intervención comunitaria. Madrid: Editorial Popular, 2001.

- La utopía possible: la intervención comunitaria en las nuevas condiciones sociales. Tenerife: Editorial Benchomo, 1994.

Moughtin, Cliff. Ubran Design: Street and Square. $3^{\text {rd }}$ ed. Oxford: Architectural Press, 2003.

Moulaert, Frank, and Flavia Martinelli, Erik Swyngedouw, Sara González, eds. Can Neighbourhoods Save the City?: Community Development and Social Innovation. Abingdon: Routledge/Taylor \& Francis Group, 2010.

Nicholson, Linda. "Civic Participation in Public Policy-Making: A Literature Review." Research findings, no. 14 (2015): 1-4. http://www.gov.scot/Resource/Doc/69582/0017808.pdf

Padilla, Samuel. "Producción de Espacio Público [X] Participación Ciudadana. El proyecto de espacio público resultado de procesos de participación ciudadana." PhD diss., Universitat de Barcelona, 2015. http://tdx.cat/handle/10803/309288

Pierre, Jon. "Rethinking Comparative Urban Politics: From Urban Regime Theory to Urban Governance?," posted August 15 th 2011. http://dx.doi.org/10. $2139 /$ ssrn.1909759

Pindado, Fernardo. "La participación no se improvisa." Revista de estudios locales, no. 87 (December 2005): 1-18.

Pinto, Ana Júlia. "Coesão urbana: o papel das redes de espaço público." PhD diss., Universitat de Barcelona, 2015. http://hdl.handle.net/10803/320186

Pradel, Marc, and Marisol García, ed. El momento de la ciudadanía. Innovación Social y Gobernanza Urbana. Madrid: La Catarata, 2018.

Reason, Peter, and Hilary Bradbury, ed. Handbook of Action Research. Participative Inquiry and Practice. London: SAGE Publications, 2001.

Remesar, Antoni, and Pol Enric. "Civic Participation Workshops in Sant Adrià de Besòs: A Creative Methodology." In Locality, Regeneration \& Divers[c]ities, edited by Sarah Bennett and John Butler, 153-158. Bristol: Intellect, 2000.

- Repensar el río. Taller de Participación ciudadana "Usos Sociales del río Besòs." Barcelona: Publicacions i Edicions de la Universitat de Barcelona, 1999, CD-ROM.

Remesar, Antoni, and Salvador García Fortes. "Building the New Barcelona. The importance of the survey on common architecture in the Cerda's Project." In To and Fro, Modernism and Vernacular Architecture, edited by Joana Cunha Leal and Maria Helena Maia, Alexandra Cardoso, 129-152. Porto: CEAA, 2013.

Ricart, Nuria. "Cartografies de La Mina: Art, espai públic, participació ciutadana." PhD diss., Universitat de Barcelona, 2009. http://hdl.handle.net/10803/1549

Ríos Díaz, Marien. “¿Hacer Ciudad? Barcelona, la construcción del paisaje, 1929-1973.” PhD diss., Universitat de Barcelona, 2017. http://hdl.handle.net/10803/481954

Salas, Xavier. "L'artista com a facilitador en els processos de participació ciutadana: el cas Baró de Viver a Barcelona." PhD diss., Universitat de Barcelona, 2015. https://www.tdx.cat/ handle/10803/308505

Sanoff, Henry. Community Participation Methods in Design and Planning. New York: John Wiley and Sons, 2000.

Till, Jeremy. "The negotiation of hope." In Architecture and Participation, edited by Peter Blundell Jones and Doina Petrescu, Jeremy Till, 23-42. London: Spon Press, 2005

UN-Habitat. "Urban Governance Index (UGI). A Tool to Measure Progress in Achieving Good Urban Governance." UN-Habitat. For a Better Urban Future, 1999. http://mirror.unhabi tat.org/downloads/docs/2232_80907_UGIndex.doc

Universal Declaration of Emerging Hüman Rights. Barcelona: Institut de Drets Humans de Catalunya, 2009. http://www2.world-governance.org/IMG/pdf_DUDHE-2.pdf

Verwijnen, Jan. "Here and Nowhere. The Making of Urban Space." On the w@terfront, no. 2 (2000): 7-12. http://revistes.ub.edu/index.php/waterfront/article/view/18724 